\title{
PENGARUH JUMLAH TEMUAN AUDIT TERHADAP OPINI AUDIT KABUPATEN/KOTA SE-SUMATERA
}

\author{
Muhammad Ichsan Siregar \\ Program Studi Akuntansi Universitas Indo Global Mandiri \\ Email: ichsan@uigm.ac.id \\ Jumadi Rudiansyah \\ Program Pasca Ilmu Akuntansi Universitas Lampung \\ Email : joy_rudiansyah@yahoo.com
}

\begin{abstract}
ABSTRAK
Penelitian ini bertujuan untuk mengetahui pengaruh jumlah temuan audit terhadap opini BPK pada pemerintah kabupaten/kota di Sumatera. Temuan audit yang diduga sangat mempengaruhi opini BPK menjadi variabel bebas pada penelitian ini yaitu temuan atas pemeriksaan SPI dan temuan atas pemeriksaan kepatuhan terhadap peraturan perundang-undangan. Jenis penelitian yang digunakan dalam penelitian ini merupakan penelitian kuantitatif dengan menggunakan data sekunder yang diperoleh dari laporan hasil pemeriksaan BPK atas LKPD kabupaten/kota. Populasi yang digunakan dalam penelitian ini adalah pemerintah daerah kabupaten dan kota seIndonesia. Pemilihan sampel menggunakan metode purposive sampling, yaitu teknik sampling yang anggota sampelnya dipilih secara khusus berdasarkan kriteria tertentu untuk tujuan penelitian. Kriteria yang digunakan dalam penentuan sampel adalah kabupaten dan kota di sumatera yang menyajikan laporan keuangan tahun 2015, yang telah mendapat laporan hasil pemeriksaan dari BPK. Hasil penelitian menyimpulkan bahwa jumlah temuan atas pemeriksaan SPI dan jumlah temuan atas pemeriksaan kepatuhan secara parsial berpengaruh terhadap opini audit Badan Pemeriksa Keuangan.
\end{abstract}

Kata Kunci: opini, jumlah temuan pemeriksaan SPI, jumlah temuan atas pemeriksaan kepatuhan

\section{PENDAHULUAN}

Tabel 1.1 Fenomena Penelitian

\begin{tabular}{|l|l|c|c|c|l|}
\hline \multirow{2}{*}{ NO } & KABUPATEN/KOTA & OPINI & $\begin{array}{c}\text { JUMLAH } \\
\text { KASUS } \\
\text { TEMUAN SPI }\end{array}$ & \multicolumn{2}{|c|}{$\begin{array}{c}\text { JUMLAH TEMUAN } \\
\text { KEPATUHAN }\end{array}$} \\
\cline { 5 - 6 } & & & & 11 & 1.647 .921 .538 \\
\hline 1 & Kab. Aceh Barat & WTP & 9 & 12 & 17.804 .756 .620 \\
\hline 2 & Kab. Aceh Besar & WTP & 4 & 9 & 13.633 .878 .659 \\
\hline 3 & Kab. Aceh Jaya & WTP & 9 & 12 & 25.406 .908 .870 \\
\hline 4 & Kab. Aceh Timur & WTP & 7 & 12 & 20.854 .013 .687 \\
\hline 5 & Kab. Dharmasraya & WTP & 8 & 13 & 6.947 .562 .108 \\
\hline 6 & Kab. Pasaman & WTP & 6 & 15 & 36.807 .772 .562 \\
\hline 7 & Kab. Bengkalis & WTP & 10 & 17 & 5.611 .726 .878 \\
\hline 8 & Kab. Kepulauan Meranti & WTP & 10 & 11 & 21.390 .810 .922 \\
\hline 9 & Kab. Kuantan Singingi & WTP & 6 & 9 & 5.275 .956 .280 \\
\hline 10 & Kab. Pelalawan & WTP & 7 & 10 & 22.266 .291 .018 \\
\hline 11 & Kab. Siak & WTP & 9 & 9 & \\
\hline 12 & Kab. Musi Banyuasin & WTP & & & 12 \\
\hline
\end{tabular}




\begin{tabular}{|c|l|c|c|c|l|}
\hline 13 & $\begin{array}{l}\text { Kab. Ogan Komering } \\
\text { Ulu }\end{array}$ & WTP & 9 & 8 & 12.190 .890 .577 \\
\hline 14 & Kota Pagar Alam & WTP & 8 & 12 & 4.829 .988 .193 \\
\hline 15 & Kota Palembang & WTP & 9 & 18 & 33.507 .899 .228 \\
\hline 16 & Kab. Karo & WDP & 5 & 5 & 682.011 .053 \\
\hline 17 & Kab. Langkat & WDP & 7 & 5 & 6.987 .841 .536 \\
\hline 18 & Kab. Lampung Selatan & WDP & 6 & 5 & 15.297 .207 .848 \\
\hline 19 & Kab. Lampung Tengah & WDP & 6 & 7 & 23.855 .127 .952 \\
\hline 20 & Kab. Ogan Ilir & WDP & 5 & 4 & 15.479 .871 .238 \\
\hline 21 & Kab. Natuna & WDP & 5 & 5 & 12.739 .061 .500 \\
\hline
\end{tabular}

Pada tabel di atas terlihat di beberapa kabupaten/kota yang memperoleh opini audit WTP, justru jumlah kasus dan nominal temuan lebih besar dari beberapa kabupaten yang mendapat opini WDP. Fenomena ini

menjadi kontradiktif dengan apa yang dinyatakan BPK dalam IHP 2014. Munculnya fenomena ini memberi signal bahwa standar pemeriksaan belum berfungsi sebagai mana mestinya.

\section{Grafik 1.1 Grafik Opini Atas LKPD Tahun Anggaran 2015}

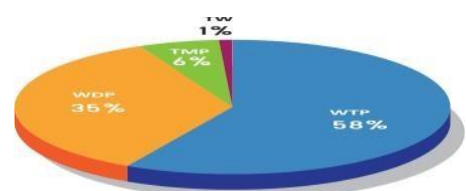

Sumber : BPK-RI melalui publikasi www.bpk.go.id diakses 17 Maret 2017

Apabila dilihat secara lebih menyeluruh, opini LKPD dalam 5 tahun terakhir (2011- 2015) mengalami perbaikan. Selama periode tersebut,
LKPD yang memperoleh opini WTP naik sebanyak 45 persen, yaitu dari $13 \%$ pada tahun 2011 menjadi 58\% pada tahun 2015 seperti digambarkan di bawah ini.

Grafik 1.2 Opini LKPD Dalam 5 Tahun Terakhir (2011-2015)

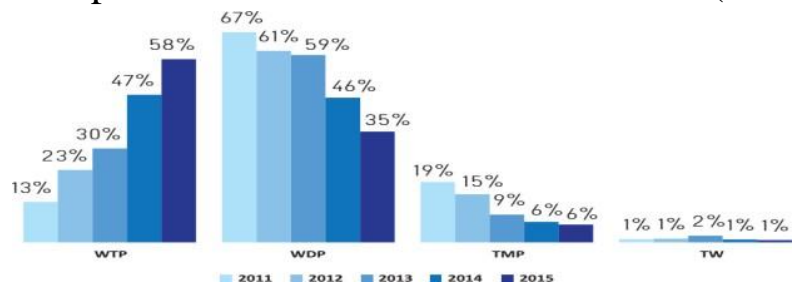

Sumber : BPK-RI melalui publikasi www.bpk.go.id diakses 17 Maret 2017

Sementara itu, berdasarkan tigkat pemerintahan, LKPD yang diperiksa pada semester I tahun 2016 terdiri atas $34 \mathrm{LK}$ pemerintah provinsi, 408 LK pemerintah kabupaten, dan 91
LK pemerintah kota. Perkembangan opini LKPD berdasarkan tigkat pemda dari tahun 2011 sampai dengan 2015 dapat dilihat pada grafik 3 berikut ini: 
Grafik 1.3 Perkembangan Opini LKPD Berdasarkan Tingkat Pemda 2011 - 2015

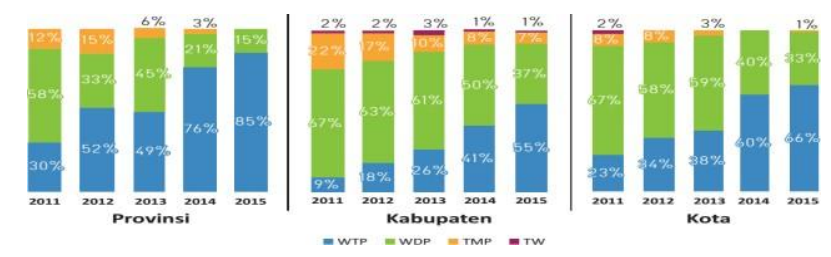

Sumber : BPK-RI melalui publikasi www.bpk.go.id diakses 17 Maret 2017

Dari grafik di atas terlihat, kenaikan opini dari tahun sebelumnya terjadi pada seluruh level pemerintahan. Pada tahun 2015 untuk pemerintah provinsi, opini WTP bertambah dari 26 LKPD menjadi 29 LKPD. Begitu pula untuk pemerintah kabupaten bertambah dari 170 LKPD menjadi 223 LKPD, pada pemerintah kota dari 56 LKPD menjadi 60 LKPD. Kenaikan opini dari WDP menjadi WTP pada 84 LKPD dan dari TW/ TMP menjadi WDP pada 17 LKPD hal ini disebabkan karena pemda telah menindaklanjuti hasil pemeriksaan BPK tahun 2014 dengan melakukan perbaikan atas kelemahan sistem pengendalian intern maupun ketiakpatuhan terhadap peraturan perundang- undangan sehingga akunakun disajikan dan diungkapkan sesuai dengan SAP.

Penentuan opini sangat tergantung dari nilai temuan audit (Atmaja dan Probohudono, 2015), dan semestinya nilai temuan untuk opini non WTP akan lebih material jika dibandingkan opini WTP. Namun untuk membuktikan secara empiris apakah nilai temuan audit pada pemerintah daerah berpengaruh terhadap opini audit maka perlu dilakukan penelitian dengan melakukan analisis terhadap LHP - LKPD. Beberapa penelitian pernah dilakukan dalam hal analisis temuan audit BPK, diantaranya yaitu
Atmaja dan Probohudono (2015), judul penelitian: Analisis Audit BPK RI Terkait Kelemahan SPI, Temuan Ketidakpatuhan dan Kerugian Negara. Penelitian ini menunjukkan hasil bahwa kelemahan sistem pengendalian akuntansi dan pelaporan (SPAP), ketidakpatuhan terhadap ketentuanperaturan perundangundangan dan temuan kerugian negara dapat mempengaruhi pertimbangan pemberian opini BPK, yang berimplikasi secara praktis bagi pemerintah daerah dalam melakukan pembenahan pengelolaan keuangan daerah.

Rahayu dan Aryani (2016) dengan judul penelitian Determinasi Temuan Pemeriksaan BPK-RI: Perspektif Karakteristik Auditee dan Karakteristik Auditor, hasil penelitian ini membuktikan bahwa diferensiasi fungsional, belanja modal, dan tipe pemerintah daerah berpengaruh terhadap jumlah temuan BPK-RI dengan arah positif, sementara ukuran pemerintah daerah, opini audit tahun sebelumnya, peringkat pemerintah daerah, kecakapan profesional, dan gender berpengaruh terhadap jumlah temuan BPK- RI dengan arah negatif. Setyaningrum dkk. (2015) dalam penelitiannya yang berjudul Pengaruh Temuan Audit, Tindak lanjut Hasil Pemeriksaan dan Kualitas Sumber Daya Manusia terhadap Opini Audit melalui 
Tingkat Pengungkapan Laporan Keuangan Kementerian/Lembaga, hasil penelitian diantaranya menyimpulkan bahwa terdapat pengaruh yang positif dan signifikan temuan audit terhadap opini BPK pada kementerian dan lembaga, dan merekomendasikan untuk melakukan penelitian pada pemerintah daerah. Gregg dan Cercelle (2007) dengan judul artikelnya How to Audit a Company's Compliance Program, menyatakan bahwa tanggapan manajemen terhadap temuan audit, dan rencana tindak lanjut yang tepat harus disertakan dalam laporan, dan pengujian ulang harus dilakukan untuk menghindari efek yang berpotensi merugikan tanpa tindakan perbaikan. Akbar dkk. (2016) dalam penelitian yang berjudul Factors Affecting the Probability of Local Government Financial Statement to Get Unqualified Opinion, menyimpulkan bahwa temuan auditor memberikan dampak signifikan terhadap opini audit karena pemerintah harus menerapkan tata kelola keuangan yang baik sehingga semakin sedikit temuan/rekomendasi yang diberikan oleh auditor maka semakin baik, ada perbedaan yang signifikan antara pemerintah daerah yang mendapatkan opini WTP dan non WTP.

Opini Wajar Tanpa Pengecualian adalah salah satu indikator pengelolaan keuangan yang akuntabel. Pemerintah daerah harus secara serius mempertimbangkan faktor-faktor yang mempengaruhi perolehan opini WTP dari BPK, dalam penelitian ini secara empiris dibuktikan temuan audit memiliki pengaruh yang signifikan terhadap probabilitas memperoleh opini WTP. Augustine et.al (2013) dalam penelitian yang berjudul Impact of Audit Evidence on Auditor's Report, menyatakan bahwa kecukupan bukti audit memiliki koefisien negatif namun dampaknya tidak signifikan terhadap opini audit, sementara hasil berbeda didapat dalam penelitian yang dilakukan oleh Niktaba dan Aslani (2015) berjudul The Effect of Audit Evidence on The Auditor's Report, menyatakan bahwa bukti audit memiliki pengaruh signifikan terhadap opini audit. Lalu penelitian Setiyawati (2016) yang berjudul Effect of Weaknesses of the Internal Control Systems

And Noncompliance With Statutory Provisions on The Audit opinion of The Audit Board of The Republic of Indonesia, menyimpulkan bahwa kelemahan sistem pengendalian internal, dan ketidakpatuhan terhadap ketentuan perundang-undangan di lingkungan Pemerintah Daerah berpengaruh terhadap opini BPK- RI.

Dari uraian tentang hasil beberapa penelitian terdahulu, maka sejalan dengan pernyataan BPK dalam IHP 2014, bahwa efektifitas SPI dan kepatuhan terhadap peraturan perundang-undangan menjadi faktor penentu opini audit. Fenomena yang penulis temukan sebagaimana diuraikan di atas yang kurang konsisten dengan IHP-BPK 2014 dan kesimpulan penelitian terdahulu, menjadi salah satu alasan penulis ingin melakukan pungujian hubungan antara temuan audit dengan opini audit, dengan maksud mencari bukti empiris sejauh mana pengaruh temuan audit terhadap opini pada pemeriksaan laporan keuangan pemerintah daerah yang dilakukan oleh BPK. Berdasarkan latar belakang dan fenomena serta hasil beberapa penelitian terdahulu yang diuraikan di atas maka penulis tertarik melakukan penelitian dengan judul "Pengaruh Jumlah Temuan Audit Terhadap Opini Audit Kabupaten/Kota se- 
Sumatera".

\section{TINJAUAN PUSTAKA}

\section{Teori Keagenan (Agenci Theory)}

Menurut Meisser, et al., (2006) dijelaskan hubungan keagenan ini mengakibatkan dua permasalahan yaitu: "terjadinya informasi asimetris (information asymmetry), dimana manajemen secara umum memiliki lebih banyak informasi mengenai posisi keuangan yang sebenarya dan posisi operasi entitas dari pemilik dan terjadinya konflik kepentingan (conflict of interest) akibat ketidak samaan tujuan, dimana manajemen tidak selalu bertindak sesuai dengan kepentingan pemilik".

Menurut Lupia \& Mc Cubbins (2000), di dalam demokrasi modern setidaknya terdapat empat ciri pendelegasian yakni: “(1) adanya prinsipal dan agen, (2) kemungkinan terjadinya konflik kepentingan, (3) adanya asimetri informasi, dan (4) prinsipal kemungkinan dapat mengurangi masalah keagenan".

Dalam Halim (2006) di paparkan bahwa prinsipal sendiri harus mengeluarkan biaya (costs) untuk mendapatkan informasi yang dibutuhkan dalam memonitor kinerja agents dan untuk menentukan struktur insentif dan monitoring yang efisien. Dalam hubungan keagenan di pemerintahan antara eksekutif dan legislatif, eksekutif adalah agen dan legislatif adalah prinsipal, di antara prinsipal dan agen senantiasa terjadi masalah keagenan, oleh karena itu, persoalan yang sering timbul di antara eksekutif dan legislatif juga merupakan persoalan keagenan. Masalah yang dihadapi legislatif dapat diartikan sebagai fenomena yang disebut agency problems. Masalah keagenan paling tidak melibatkan dua pihak, yakni prinsipal, yang memiliki otoritas untuk melakukan tindakantindakan, dan agen, yang menerima pendelegasian otoritas dari prinsipal. Dalam konteks pembuatan kebijakan oleh legislatif, legislatif adalah prinsipal yang mendelegasikan kewenangan kepada agen seperti pemerintah atau panitia di legislatif untuk membuat kebijakan baru. Hubungan keagenan di sini terjadi setelah agen membuat usulan kebijakan dan berakhir setelah usulan tersebut diterima atau ditolak (Halim, 2006).

\section{Teori Legitimasi (Legitimacy Theory)}

Pengertian legitimasi teori dikemukakan oleh O'Donovan (2002) yaitu: "Legitimacy theory as the idea that in order for an organization to continue operating successfully, it must act in a manner that society deems socially acceptable".

Dari pengertian di atas, legitimacy theory mengandung arti bahwa organisasi/perusahaan secara berkesinambungan harus memastikan apakah mereka telah beroperasi di dalam norma-norma yang dijunjung masyarakat dan memastikan bahwa aktivitas mereka bisa diterima pihak luar yaitu masyarakat disekelilingnya (dilegitimasi).

Menurut Laan (2009) dalam Setiawati (2012) bahwa: "Teori legitimasi menggunakan motivasi untuk mendapatkan pengesahan atau penerimaan dari masyarakat".

Lebih lanjut, Ashforth and Gibbs (1990) menjelaskan bahwa: "legitimasi merupakan proses bagaimana suatu entitas pelaporan berusaha memperoleh, menjaga atau memelihara, dan memperbaiki legitimasi organisasi di mata para stakeholdernya". 


\section{Kerangka Konseptual}

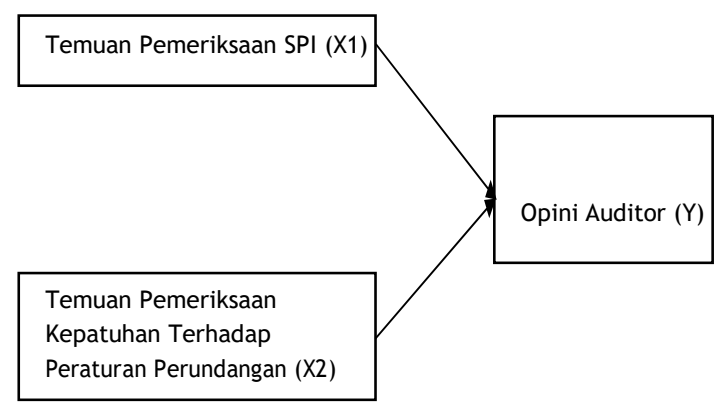

\section{Pengembangan Hipotesis}

Penulis berpendapat bahwa pemda yang memiliki pengendalian internal yang lebih baik akan mengurangi munculnya permasalahan-permasalahan yang berdampak pada sedikitnya jumlah temuan pemeriksaan yang dihasilkan BPK-RI, jika jumlah temuannya makin sedikit maka kemungkinan opininya akan semakin baik. Dari uraian di atas, maka dirumuskan hipotesis dalam penelitian ini adalah:

H1 : jumlah temuan audit atas SPI

berpengaruh negatif terhadap opini audit

Dalam melaksanakan audit terhadap Pemerintah Daerah kabupaten/kota, BPK melakukan uji petik terhadap transaksi-transaksi yang dilakukan selama satu tahun anggaran. Pemeriksaan dilakukan dengan membandingkan praktik yang dilakukan di lapangan dengan yang semestinya menurut peraturan perundangan yang berlaku dalam tata kelola keuangan negara. Peraturan perundang-undangan di bidang pengelolaan keuangan negara maupun dearah dijadikan acuan/standar BPK dalam menilai praktik-praktik yang dilakukan oleh pemerintah daerah, apakah sudah sesuai dengan pasal demi pasal peraturan perundangan tersebut.

Jika ditemukan ketidak sesuaian atau pelanggaran maka akan menjadi catatan sebagai temuan audit atas ketidak patuhan, hal ini sesuai dengan standar pemeriksaan keuangan negara, dimana audit terhadap keuangan negara salah satu yang diperiksa ialah kepatuhan terhadap peraturan perundang-undangan. Hasil penelitian yang dilakukan Atmaja dan Probohudono (2015), menyimpulkan bahwa ketidakpatuhan terhadap ketentuan peraturan perundang- undangan dan temuan kerugian negara dapat mempengaruhi pertimbangan pemberian opini BPK, sejalan juga dengan hasil penelitian Setiyawati (2016), yang menyimpulkan bahwa ketidakpatuhan terhadap ketentuan perundang-undangan tentang entitas pelaporan dan akuntansi di lingkungan pemerintah daerah berpengaruh terhadap opini audit Badan Pemeriksa Keuangan Republik Indonesia.

Penulis berpendapat bahwa pemda yang melakukan pelanggaran terhadap peraturan perundangan dalam pengelolaan keuangan negara maka akan munculnya permasalahan-permasalahan yang berdampak pada tingginya jumlah temuan pemeriksaan yang dihasilkan BPK-RI, jika jumlah temuannya makin tinggi maka kemungkinan opininya akan semakin tidak baik.

Dari uraian di atas, maka dirumuskan hipotesis dalam penelitian ini adalah:

$\mathrm{H} 2$ : jumlah temuan audit atas kepatuhan terhadap peraturan perundang- undangan berpengaruh 
negatif terhadap opini audit

\section{METODOLOGI PENELITIAN}

\section{Populasi dan Sampel Penelitian}

Menurut Usman dan Akbar (2006), populasi ialah semua nilai baik hasil perhitungan maupun pengukuran, baik kuantitatif maupun kualitatif, dari karakteristik tertentu mengenai sekelompok objek yang lengkap dan jelas. Sedangkan sampel adalah sebagian objek yang diambil dari keseluruhan objek yang diteliti dan dianggap mewakili seluruh populasi (Notoatmojo, 2003). Populasi dalam penelitian ini adalah pemerintah kabupaten/kota di Indonesia. Sampel yang dipilih adalah kabupaten/kota se-sumatera yang memiliki data laporan keuangan pemerintah daerah tahun 2015 yang telah diaudit BPK-RI, dan disajikan dalam bentuk laporan hasil pemeriksaan (LHP) BPK. Alasan pemilihan sampel ini juga berdasarkan pertimbangan daerah kabupaten dan kota di Sumatera memiliki karakteristik ekonomi dan geografis yang sama dan secara teoritis dan empiris berbeda dengan Jawa - Bali (Abdullah dan Halim, 2003).

\section{Jenis dan Sumber Data}

Penelitian ini menggunakan data sekunder yang berasal dari laporan keuangan pemerintah daerah (LKPD) yang didapat dari laporan hasil audit (LHP) BPK - RI. Data yang digunakan adalah LHP tahun 2015, yang terdiri dari opini atas LKPD, jumlah kasus temuan atas pemeriksaan SPI dan jumlah nilai temuan atas pemeriksaan kepatuhan. Sumber data adalah soft copy LHP BPKRI atas pemeriksaan LKPD kabupaten/kota yang didapat dari BPK-RI kantor pusat.

Teknik pengumpulan data yang digunakan dalam penelitian ini adalah teknik dokumentasi yaitu pengumpulan data dengan cara membaca, mempelajari dan mengutip catatan-catatan yang diperoleh dari dokumen laporan keuangan pemerintah daerah dan laporan hasil pemeriksaan BPK-RI, buku-buku akuntansi pemerintahan, jurnal, artikel dan peraturan perundangan yang terkait dengan permasalahan yang diteliti. Jumlah sampel yang dipilih dalam penelitian berjumlah sebanyak 146 kabupaten dan kota di pulau Sumatera, yang memenuhi syarat sebagai sampel. Data penelitian yang terdiri dari opini hasil audit dikelompokan dalam kategori opini WTP dan selain WTP, jumlah temuan SPI diproksikan dengan jumlah kasus, dan jumlah temuan atas kepatuhan terhadap peraturan perundang- undangan diproksikan dalam bentuk rasio materialitas nilai temuan yaitu jumlah temuan dalam rupiah dibandingkan dengan nilai belanja APBD dikalikan 100 . Pengolahan data statistik menggunakan aplikasi SPSS (Statistical Package for Social Science) versi 21.

\section{Variabel Penelitian dan Definisi Operasional Variabel Variabel Penelitian}

Menurut Sekaran (2006), variabel adalah sesuatu yang dapat membedakan atau membawa variasi pada nilai. Penelitian ini melibatkan dua variabel yaitu variabel terikat dan variabel bebas. Variabel bebas adalah variabel yang mempengaruhi variabel terikat antara positif atau negatif. Variabel bebas dalam penelitian ini adalah temuan audit atas pemeriksaan SPI dan temuan audit atas pemeriksaan kepatuhan terhadap peraturan perundang-undangan pada laporan keuangan pemerintah 
kabupaten/kota di Sumatera tahun anggaran 2015. Variabel terikat (dependent variable) merupakan variabel yang menjadi pusat perhatian utama bagi peneliti (Sekaran, 2006), variabel terikat dalam penelitian ini adalah opini audit atas pemeriksaan LKPD pemerintah kabupaten/kota di Sumatera tahun 2015.

\section{Definisi Operasional Variabel}

Opini audit adalah gambaran hasil pemeriksaan secara keseluruhan tentang LKPD yang diperiksa. Berdasarkan Undang-Undang Nomor 15 Tahun 2004 tentang Pemeriksaan Pengelolaan dan Tanggung Jawab Keuangan Negara disebutkan bahwa terdapat empat (4) jenis opini audit yang diberikan oleh Badan Pemeriksa Keuangan (BPK) atas hasil pemeriksaan laporan keuangan pemerintah (LKP), yaitu (a) wajar tanpa pengecualian, (b) wajar dengan pengecualian, (c) tidak wajar, dan (d) menolak memberikan pendapat (disclaimer).

Dalam penelitian ini penulis memilih opini sebagai variabel dependen, opini audit diukur dengan menggunakan kategori wajar tanpa pengecualian atau lainnya, yaitu jika memperoleh opini wajar tanpa pengecualian (WTP) diberi kode 1 (satu), dan jika memperoleh opini selain wajar tanpa pengecualian (wajar dengan pengecualian (WDP), tidak wajar (TW), tidak memberikan pendapat (TMP)) diberi kode 0 (nol). Pengukuran opini audit dengan membuat data kategori seperti ini mengacu pada penelitian sebelumnya yang pernah dilakukan oleh Setiyawati (2016), dan Augustine, et.al. (2013).

Temuan atas SPI adalah temuan pemeriksaan atas sistem pengendalian internal pemerintah daerah, diperoleh dari pengujian atas praktik-praktik yang dilakukan apakah sudah memenuhi prinsip-prinsip pengendalian yang memadai, baik terkait penatausahaan pelaksanaan APBD, pencatatan akuntansi dan pelaporan maupun struktur organisasi dalam pelaksanaan tugas dan fungsinya (BPK, 2014). Karena temuan atas pemeriksaan SPI sebagian besar hanya bersifat pernyataan atau narasi dan tidak terdapat nominalnya maka dalam penelitian ini temuan atas SPI dihitung berdasarkan jumlah kasus, hal ini sejalan dengan penelitian Setiyawati (2016) dan Atmaja dan Probohudono (2015).

Temuan audit atas kepatuhan terhadap peraturan perundangan adalah temuan audit atas peraktik-peraktik yang dilakukan yang melanggar ketentuan peraturan perundangan. Temuan atas ketidakpatuhan terbagi menjadi lima klasifikasi temuan, yaitu indikasi/potensi kerugian daerah, kekurangan penerimaan, kelemahan administrasi, ketidakhematan, dan ketidakefektifan.

Variabel temuan audit atas kepatuhan pada penelitian ini mengacu pada penelitian Setiyawati (2016) dan penelitian Sudarsana dan Rahardjo (2013), namun dalam penelitian ini temuan audit atas kepatuhan diukur bukan berdasarkan jumlah kasus, tetapi dengan melihat tingkat materialitas nilai temuan, yaitu nilai temuan audit (dalam rupiah) dibandingkan dengan total belanja lalu dikalikan seratus. Hal ini konsisten dengan penelitian yang dilakukan Mustikarini dan Fitriasari (2012), variabel temuan audit BPK atas kepatuhan dalam penelitian ini menggunakan rumus :

Temuan audit atas kepatuhan $=$ Jumlah temuan (dalam rupiah) Total Realisasi Belanja Daerah x 100 


\section{Metode Analisis}

\section{Uji Regresi Logistik}

Regresi logistik (logistic regression) merupakan suatu bentuk regresi yang digunakan pada saat variabel tak bebas (dependent variabel) bersifat kategorik, dan regresi logistik biner digunakan jika kategori pada variabel tak bebas bersifat dikotomus, yaitu terdiri dari dua kategori (Asra dkk. 2017 : p. 54).

Dari 146 kabupaten/kota sesumatera yang dijadikan sampel sebanyak 75 kabupaten/kota memperoleh opini WTP, 65 kabupaten/kota memperoleh opini WDP, 6 kabupaten/kota memperoleh opini disclaimer, dan tidak satupun yang memperoleh opini tidak wajar. Dari data tersebut terlihat secara dominan perolehan opini didominasi oleh WTP dan WDP. Dalam penelitian ini penulis menjadikan opini audit sebagai variabel terikat dan berusaha untuk mengukur peluang atau kecendrungan suatu kabupaten/kota dalam memperoleh opin WTP dari auditor. Karena yang ingin diketahui adalah peluang atau kecendrungan maka analisis yang cocok adalah dengan analisis regresi logistik, dan untuk alat analisis statistik ini, syaratnya yaitu variabel terikat penelitian harus dalam bentuk data dikotomi atau dua kategorik. Untuk itu, penelitian ini membedakan variabel terikat menjadi dua ketegori yaitu antara WTP dan Tidak WTP. Hasil uji statisitik regresi logistik dapat meramal sejauh mana peluang pemerintah daerah dapat memperoleh opini WTP, dilihat dari jumlah temuan audit, baik temuan SPI maupun temuan kepatuhan.

Langkah - langkah pengujian yang akan dilakukan adalah sebagai berikut:
1. Variabel
respon/dependent

dikategorikan menjadi data dikotomi yakni 0 dan 1.

2. Melakukan uji signifikansi model dengan melakukan uji keseluruhan, untuk mengetahui apakah minimal ada satu variabel bebas yang berpengaruh signifikan di dalam model. Hipotesis yang diuji dalam pengujian signifikansi model ialah:

$\mathrm{H} 0: \beta 1=\beta 2=0$

$\mathrm{H} 1$ : minimal ada satu $\beta \mathrm{j} \neq 0 \quad \mathrm{j}=1,2$

3. Uji kesesuaian model regresi logistik dilakukan untuk menguji layak atau tidaknya model yang dihasilkan. Hipotesis yang digunakan adalah:

H0 : model cocok

H1 : model tidak cocok

Jika p-value $<\alpha$ maka H0 ditolak, dan jika gagal tolak H0, maka model cocok.

4. Dengan menggunakan variabel penjelas jumlah temuan audit atas SPI dan temuan atas audit kepatuhan akan didapatkan model peluang persamaan regresi logistik:

$$
\begin{gathered}
\pi(x)=\frac{\exp (\beta 0+\beta X 1+\beta 2 X 2)}{\exp (\beta 0+\beta 1 X 1+\beta 2 X 2)} 1+
\end{gathered}
$$

\section{Pengujian Hipotesis}

Pengujian secara statistik dilakukan dengan beberapa tahap seperti diuraikan di atas, sebelum dilakukannya pengujian hipotesis. Data yang telah dikumpulkan dianalisis dengan menggunakan alat analisis statistik yaitu analisis regresi logistik dengan model persamaan sebagai berikut:

$$
\operatorname{Ln}(\underline{\mathrm{p}})=(\beta 0+\beta 1 \mathrm{X} 1+\beta 2 \mathrm{X} 2)
$$

Keterangan:

$\mathrm{p}=$ peluang/probabilita $\mathrm{Y}$ memperoleh opini WTP X1 = Jumlah kasus atas temuan SPI

$\mathrm{X} 2$ = materialitas temuan atas kepatuhan (rasio temuan terhadap total belanja $\mathrm{x} 100$ ) 
$\beta 0=$ konstanta

$\beta 1 \beta 2=$ koefisien variabel independen

Dari model regresi logostik yang terbentuk maka selanjutnya dilakukan pengujian Odss ratio yang merupakan ukuran untuk mengetahui pengaruh variabel bebas terhadap kecenderungan atau peluang suatu kategori atau perbandingan tingkat resiko relatif dua buah nilai variabel penjelas. Nilai odds ratio ini yang menunjukan besar atau kecilnya pengaruh variabel bebas terhadap peluang atau kecendrungan variabel terikatnya, sedangkan arah positif atau negatif pengaruh masing- masing variabel bebas terhadap varibel terikat dapat dilihat dari tanda koofisien variabel bebas dalam model.

\section{HASIL DAN PEMBAHASAN}

Deskriptif Statistik

Penelitian ini bermaksud memberikan bukti empiris tentang pengaruh temuan audit terhadap opini dalam pemeriksaan laporan keuangan pemerintah kabupaten/kota yang dilaksanakan oleh BPK-RI. Beberapa faktor yang diduga sangat mempengaruhi

opini audit pada pemerintah daerah diantaranya ialah jumlah temuan atas pengujian SPI dan jumlah temuan atas pengujian kepatuhan terhadap peraturan perundangan, dalam penelitian ini temuan audit dijadikan variabel bebas, sedangkan opini audit menjadi variabel tak bebas. Dari 146kabupaten/kotasesumaterayang dijadikan sampel, terdapat 75 kabupaten/kota memperoleh opini WTP, sebanyak 65 kabupaten/kota memperoleh opini WDP, sebanyak 6 kabupaten/kota memperoleh opini disclaimer, dan tidak satupun yang memperoleh opini tidak wajar. Pada data penelitian didapat bahwa jumlah kasus tertinggi untuk temuan SPI adalah sejumlah 20 kasus, terjadi pada Kabupaten Indra Giri Hulu, memperoleh opini WDP. Jumlah kasus temuan SPI terkecil yaitu sejumlah 3 kasus terjadi di Kabupaten Agam, Kota Payakumbuh, Kabupaten Batang Hari, Kabupaten Muara Enim dan Kabupaten Bengkulu Tengah, dan kesemuanya memperoleh opini WTP. Sedangkan rata-rata jumlah kasus temuan atas pemeriksaan SPI adalah sebesar 7,91 kasus. Sementara itu ditemukan adanya daerah dengan opini WTP namun temuan pemeriksaan SPI relatif tinggi, yaitu disajikan dalam tabel di bawah ini:

Tabel 4.1

Daftar Kabupaten/Kota Mendapat Opini WTP Namun Temuan SPI Tinggi

\begin{tabular}{|c|l|c|c|}
\hline NO & KABUPATEN/KOTA & OPINI & $\begin{array}{c}\text { TEMUAN SPI } \\
\text { (DALAM JUMLAH } \\
\text { KASUS) }\end{array}$ \\
\hline 1 & Kab. Aceh Barat & WTP & 9 \\
\hline 2 & Kab. Aceh Jaya & WTP & 9 \\
\hline 3 & Kab. Aceh Tamiang & WTP & 9 \\
\hline 4 & Kab. Bener Meriah & WTP & 9 \\
\hline 5 & Kab. Simeulue & WTP & 9 \\
\hline 6 & Kota Lhokseumawe & WTP & 9 \\
\hline 7 & Kab. Tanah Datar & WTP & 9 \\
\hline 8 & Kab. Bengkalis & WTP & 10 \\
\hline 9 & Kab. Kepulauan Meranti & WTP & 10 \\
\hline
\end{tabular}




\begin{tabular}{|c|l|c|c|}
\hline 10 & Kab. Siak & WTP & 9 \\
\hline 11 & Kab. Musi Banyuasin & WTP & 9 \\
\hline 12 & Kab. Ogan Komering Ulu & WTP & 9 \\
\hline 13 & Kota Lubuklinggau & WTP & 9 \\
\hline 14 & Kota Palembang & WTP & 9 \\
\hline 15 & Kab. Bintan & WTP & 9 \\
\hline 16 & Kota Batam & WTP & 9 \\
\hline
\end{tabular}

Ada juga daerah yang memperoleh opini tidak WTP namun jumlah temuan atas pemeriksaan SPI relatif rendah (hanya kurang dari 7 kasus), seperti disajikan di bawah ini:

\section{Tabel 4.2}

\section{Daftar Kabupaten Mendapat Opini WDP}

Namun Temuan SPI Rendah

Untuk jumlah temuan pemeriksaan kepatuhan nilai terbesar adalah sebesar 9,11\% yaitu terjadi di Kabupaten Samosir dengan opini tidak memberikan pendapat

Tabel 4.3

Daftar Kabupaten Mendapat Opini WTP Namun Temuan Keapatuhan Tinggi

\begin{tabular}{|l|l|l|l|}
\hline NO & KABUPATEN/KOTA & OPINI & $\begin{array}{c}\text { TEMUAN } \\
\text { KEPATUHAN } \\
\text { (DALAM } \\
\text { RATIO) }\end{array}$ \\
\hline 1 & Kab. Aceh Jaya & WTP & 1,543 \\
\hline 2 & Kab. Aceh Timur & WTP & 1,688 \\
\hline 3 & Kab. Tapanuli Selatan & WTP & 2,323 \\
\hline 4 & Kab. Dharmasraya & WTP & 2,605 \\
\hline
\end{tabular}

Selain itu ditemukan juga beberapa daerah yang memperoleh opini tidak WTP namun jumlah temuan atas pemeriksaan kepatuhannya realtif kecil (kurang dari 0,5\%) seperti disajikan di bawah ini: (disclaimer opinion). Nilai terkecil atas temuan pemeriksaan kepatuhan adalah sebesar $0,007 \%$ yaitu pada Kabupaten Agam, dengan raihan opini WTP. Sedangkan nilai rata-rata temuan atas pemeriksaan kepatuhan adalah sebesar $1,30 \%$. Pada pengolahan data penelitian ditemukan juga beberapa daerah yang memperoleh opini WTP namun jumlah temuan atas pemeriksaan kepatuhannya ralatif besar (di atas 1,5\%), seperti disajikan dalam tabel berikut ini: 
Tabel 4.4

Daftar Kabupaten/Kota Opini WDP Namun Temuan Keapatuhan Rendah

\begin{tabular}{|c|l|c|c|}
\hline NO & \multicolumn{1}{|c|}{ KABUPATEN/KOTA } & OPINI & $\begin{array}{c}\text { TEMUAN } \\
\text { SPI } \\
\text { (DALAM } \\
\text { JUMLAH } \\
\text { KASUS) }\end{array}$ \\
\hline 1 & Kab. Karo & WDP & 5 \\
\hline 2 & Kab. Nias Barat & WDP & 6 \\
\hline 3 & Kab. Padang Lawas & WDP & 6 \\
\hline 4 & Kota Binjai & WDP & 5 \\
\hline 5 & Kab. Sijunjung & WDP & 6 \\
\hline 6 & Kab. Ogan Ilir & WDP & 5 \\
\hline 7 & $\begin{array}{l}\text { Kab. Penukal Abab } \\
\text { Lematang Ilir }\end{array}$ & WDP & 6 \\
\hline 8 & Kab. Rejang Lebong & WDP & 5 \\
\hline 9 & Kab. Lampung Selatan & WDP & 6 \\
\hline 10 & Kab. Lampung Tengah & WDP & 6 \\
\hline 11 & Kab. Natuna & WDP & 5 \\
\hline
\end{tabular}

\begin{tabular}{|c|l|l|c|}
\hline NO & KABUPATEN/KOTA & OPINI & $\begin{array}{c}\text { TEMUAN } \\
\text { KEPATUHAN } \\
\text { (DALAM RATIO) }\end{array}$ \\
\hline 1 & Kab. Karo & WDP & 0,051 \\
\hline 2 & Kab. Langkat & WDP & 0,361 \\
\hline 3 & Kab. Nias & WDP & 0,019 \\
\hline 4 & Kab. Simalungun & WDP & 0,302 \\
\hline 5 & Kab. Tapanuli Tengah & WDP & 0,432 \\
\hline 6 & Kota Pematangsiantar & WDP & 0,160 \\
\hline 7 & Kab. Pasaman Barat & WDP & 0,199 \\
\hline 8 & Kab. Solok & WDP & 0,164 \\
\hline 9 & Kab. Indragiri Hilir & WDP & 0,492 \\
\hline 10 & Kab. Kampar & WDP & 0,375 \\
\hline 11 & Kota Bengkulu & WDP & 0,365 \\
\hline 12 & Kab. Bangka Selatan & WDP & 0,122 \\
\hline 13 & Kab. Bangka Tengah & WDP & 0,170 \\
\hline 14 & Kota Pangkalpinang & WDP & 0,284 \\
\hline
\end{tabular}

\section{Hasil Analisis Data}

\section{Uji Regresi Logistik}

Pengujian data penelitian dilakukan dengan beberapa tahapan uji statistik, di bawah ini akan dibahas dan dijelaskan hasil tahap demi tahap pengujian data.

\section{Variabel Respon Dikategorikan Menjadi Data Biner}

Atas informasi yang didapat dari laporan hasil pemeriksaan (LHP) BPK atas audit laporan keuangan pemerintah daerah (LKPD) kabupaten dan kota di Sumatera, maka data dikelompokan dalam kelompok variabel terikat dan variabel bebas. Opini audit sebagai Variabel terikat dibuat menjadi dua kategori (data dikotomi/biner) yaitu WTP dan selain WTP, untuk opini yang kategori WTP diberi kode 1 (satu), dan untuk opini yang kategori selain WTP diberi kode 0 (nol).

Hasil pengolahan data menggunakan SPSS yang mengelompokan data variabel tak bebas menjadi data biner dapat dilihat pada tabel 4.5 di bawah ini.

Tabel 4.5

Variabel Tak Bebas Dalam

Data Biner

\begin{tabular}{|l|l|}
\hline Original Value & Internal Value \\
\hline Tdk & 0 \\
WTP & \\
WTP & 1 \\
\hline \multicolumn{2}{|l|}{ Sumber: data diolah }
\end{tabular}

\section{Uji Signifikansi Model}

Melakukan uji signifikansi model dengan melakukan uji keseluruhan, untuk mengetahui apakah minimal ada satu variabel bebas yang signifikan di dalam model. Dalam uji statistik dalam penelitian ini ditetapkan tingkat signifikansi sebesar $5 \%(\alpha=0,05)$. Hasil pengujian model ini dapat diketahui dengan mengamati hasil statistik yaitu nilai stat uji $G$ pada tabel omnibus test of model coefficients, nilai stat uji $\mathrm{G}$ ini adalah nilai chi-square. Uji signifikansi model ini juga dapat diketahui melalui nilai $p$-value pada tingkat signifikansi yang ditetapkan sebesar $\alpha=$ 
0,05, jika p- value < 0,05 maka H0 ditolak. Hasil uji statistik untuk uji signifikansi model dapat dilihat pada Tabel 4.6 di bawah ini.

Pada tabel di atas dapat dilihat bahwa nilai chi-square $=80,357$ berarti $\beta \mathrm{j}$ $\neq 0$, lalu nilai $p$-value $=0,000<0,05$, sehingga HO ditolak, yang berarti bahwa minimal ada satu variabel bebas yang signifikan di dalam model.

\section{Uji Kesesuaian Model}

Uji kesesuaian model dilakukan untuk menguji cocok atau tidaknya model yang dihasilkan. Untuk mengetahui cocok atau tidaknya model maka dilakukan uji Hosmer and Lemwshow test, jika nilai pvalue hasil uji statistik didapat lebih besar dari $\alpha=0,05$ maka $\mathrm{H} 0$ tidak ditolak yang berarti model cocok, sebaliknya jika nilai p-value hasil uji statistik didapat lebih kecil dari $\alpha=0,05$ maka $\mathrm{H} 0$ ditolak yang berarti model tidak cocok. Hasil uji Hosmer and Lemeshow Test dapat dilihat pada Tabel 4.7 di bawah ini.

Tabel 4.7

Hasil Uji Hosmer and Lemeshow Test

\begin{tabular}{|r|c|l|l|}
\hline Step & $\begin{array}{c}\text { Chi- } \\
\text { square }\end{array}$ & df & Sig. \\
\hline 1 & 4,878 & 8 &, $\mathbf{7 7 1}$ \\
\hline
\end{tabular}

Dari hasil pengujian Hosmer and Lemeshow Test di atas didapat nilai pvalue sebesar 0,771 ( $>\alpha=0,05)$, yang berarti H0 tidak ditolak, dan model dinyatakan cocok. Untuk mengetahui tingkat ketepatan model dalam mengklasifikasikan observasi dapat pula dilihat dari hasil uji statistik menggunakan Classification Table dengan mengamati kolom percentage correct dan baris overall percentage. Hasil uji tingkat ketepatan model dapat dilihat pada tabel 4.8 di bawah ini.

Tabel 4.8

Hasil Uji Ketepatan Model

Tabel 4.6

Hasil Uji Signifikansi Model

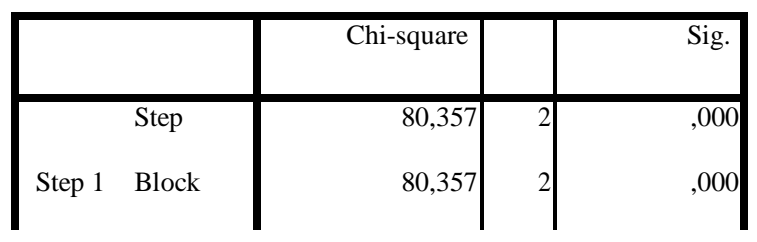

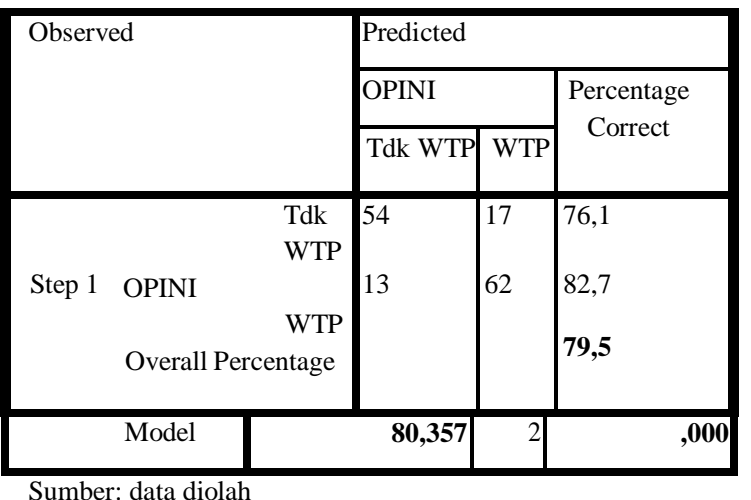


Dari hasil uji ketepatan model di atas didapat nilai $79,5 \%$ yang berarti bahwa model penelitian ini mampu mengklasifikasikan observasi objek penelitian dengan benar sebesar 79,5\%.Model Penelitian

$$
\begin{gathered}
\pi(x)=\frac{\exp (\beta 0+\beta X 1+\beta 2 X 2)}{\operatorname{Ln}(\underline{\mathrm{p}})=(\beta 0+\beta 1 \mathrm{X} 1+\beta 2 \mathrm{X} 2)} 1+\exp (\beta 0+\beta 1 X 1+\beta 2 X 2) \\
1-p
\end{gathered}
$$

Dari rumusan model di atas dilakuan pengolahan data penelitian yang hasilnya dapat dilihat pada tabel 4.9 di bawah ini.

Tabel 4.9

Hasil Perumusan Model Penelitian

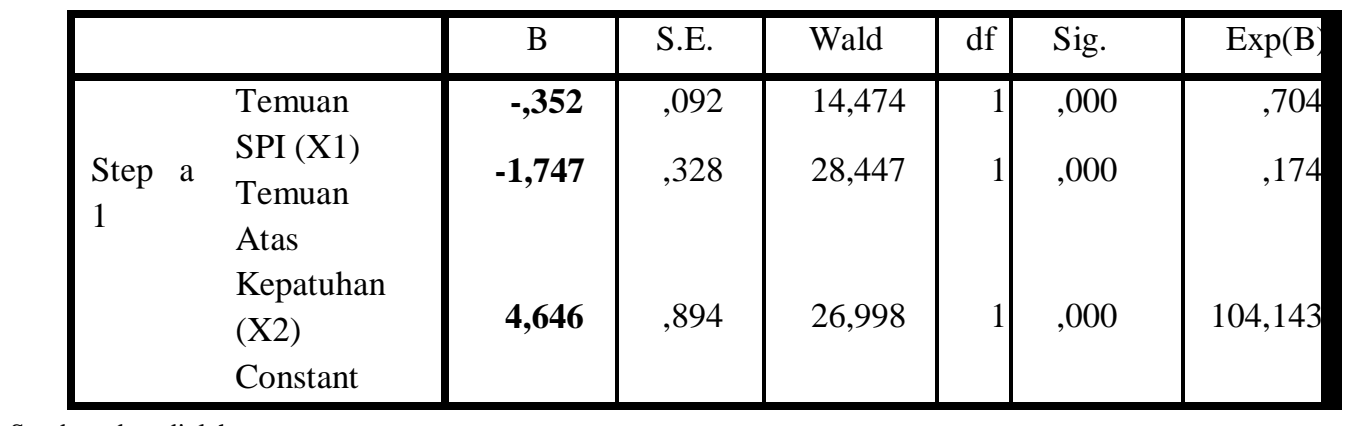

Sumber: data diolah

\section{Pengujian Hipotesis}

Dalam pengujian hipotesis model regresi logistik maka yang diuji adalah apakah H0 ditolak atau tidak ditolak (Asra, dkk. 2017). Untuk hipotesis satu (H1), hipotesis nol (H0)-nya adalah sebagai berikut:

H0 : jumlah temuan audit atas SPI tidak berpengaruh negatif terhadap opini audit. Dari hasil uji statistik sebagaimana Tabel 4.9 di atas, nilai statistik p- value untuk temuan SPI nilainya diperoleh 0,000 lebih kecil dari nilai signifikansi $\alpha=0,05$, dan hasil perumusan koofesien model penelitian atas temuan SPI adalah sebesar 0,352, maka dapat disimpulkan bahwa temuan atas pemeriksaan SPI oleh BPK
Dengan menggunakan variabel penjelas jumlah temuan audit atas SPI dan temuan atas audit kepatuhan akan didapatkan model peluang persamaan regresi logistik: 
Tabel 4.9 di atas, nilai statistik p- value untuk temuan atas kepatuhan terhadap peraturan perundang-undangan diperoleh 0,000 lebih kecil dari nilai signifikansi $\alpha=$ 0,05, dan hasil perumusan koofesien model penelitian untuk temuan atas pemeriksaan kepatuhan terhadap peraturan perundang-undangan adalah sebesar 1,747, maka dapat disimpulkan bahwa jumlah temuan atas pemeriksaan kepatuhan terhadap peraturan perundangundangan oleh BPK pada pemerintah kabupaten dan kota di Sumatera tahun 2015 berpengaruh terhadap opini audit dengan arah negatif. Dengan berpedoman pada hasil analisis data penelitian sebagaimana diuraikan di atas maka disimpulkan bahwa untuk hipotesis dua, H0 ditolak.

\section{PEMBAHASAN}

Dari uaraian hasil analisis data sebagaimana di atas diperoleh hasil bahwasanya jumlah temuan atas pemeriksaan SPI dan jumlah temuan atas pemeriksaan kepatuhan terhadap peraturan perundang-undangan oleh BPK-RI terhadap kabupaten dan kota di Sumatera tahun 2015 secara parsial terbukti berpengaruh terhadap opini audit. Hasil uji statistik baik jumlah temuan SPI maupun jumlah temuan atas pemeriksaan kepatuhan menghasilkan nilai p-value sebesar 0,000 yang jelas lebih kecil dari signifikansi $(\alpha)$ yang ditetapkan 0,05 , hal ini berarti bahwa baik jumlah temuan pemeriksaan SPI maupun jumlah temuan atas pemeriksaan kepatuhan secara parsial terbukti berpengaruh terhadap opini audit. Selanjutnya pada perumusan model didapatkan bahwa koofesien parameter untuk kedua variabel bebas ini memiliki tanda negatif, hal ini berarti bahwa pengaruh variabel bebas ini terhadap variabel terikat secara parsial arahnya adalah negatif, ini berarti bahwa semakin besar jumlah temuan SPI maka peluang pemda untuk memperoleh opini WTP semakin berkurang, begitu juga dengan temuan kepatuhan, semakin besar jumlah temuan atas pemeriksaan kepatuhan maka peluang pemda untuk memperoleh opini WTP semakin berkurang pula.

Dari hasil pengujian kesesuain model dengan uji Hosmer and Lemeshow Test didapat nilai $\mathrm{p}$-value sebesar 0,771 > $\alpha=0,05$, hal ini bermakna bahwa model yang dirumuskan cocok untuk memprediksi peluang yang akan terjadi terhadap variabel tak bebas sebagai akibat pengaruh yang ditimbulkan oleh variabel bebas. Tingkat ketepatan model dalam mengklasifikasikan observasi dapat pula dilihat dari hasil uji statistik menggunakan Classification Table dengan mengamati kolom percentage correct dan baris overall percentage, pada tabel 4.8 di atas diperoleh angka 79,5 yang berarti bahwa model penelitian ini mampu mengklasifikasikan observasi objek penelitian dengan benar sebesar 79,5\%.

Pada penelitian ini dari sampel 146 pemerintah kabupaten dan kota, observasi mampu diklasifikasikan dengan benar sejumlah 116 sampel. Dari data menurut tabel 4.8 dapat dijelaskan bahwa dari 79 kabupaten kota yang diprediksikan oleh model untuk opini WTP ternyata hanya sebanyak 62 kabupaten kota saja yang secara tepat diprediksikan memeproleh opini WTP, dan dari 67 kabupaten/kota yang diprediksikan oleh model untuk opini tidak WTP, ternyata hanya 54 kabupaten/kota yang secara tepat diprediksikan memperoleh opini tidak WTP. Sementara tidak tepat dalam memprediksi opini sejumlah 30 kabupaten/kota. 
Model memprediksi beropini WTP tapi ternyata opini sesungguhnya tidak WTP sebanyak 17 kabupaten/kota, dan diprediksi memperoleh opini tidak WTP, namun ternyata opini sesungguhnya adalah WTP sebanyak 13 kabupaten/kota. Hal ini berarti bahwa ada faktor-faktor lain diluar yang dijadikan variabel bebas penelitian yang mempengaruhi opini auditor BPK. Faktor tersebut bisa saja diduga akibat pengaruh subyektifitas auditor sebagai akibat standar audit belum mengatur satandar batasan temuan audit untuk pemberian opini.

Terdapat 30 kabupaten/kota yang opini sesungguhnya berbeda dengan yang diprediksikan oleh hasil uji statistik, berarti secara empiris jumlah temuan berpengaruh terhadap opini audit sifatnya hanya kecenderungan. Hal tersebut bisa dilihat dari masih terdapat $19,5 \%$ dari data penelitian yang tidak cocok dengan prediksi model penelitian ini.

Dari hasil perumusan model penelitian pada tabel 4.9 dapat dilihat selain koofsien parameter yang memiliki arah negatif, nilai $\mathrm{p}$-value kedua variabel bebas memiliki nilai sama yaitu 0,000 yang berarti bahwa kedua variabel bebas ini berpengaruh terhadap variabel terikat dengan arah negatif.

Selanjutnya melalui tabel 4.9 dapat dijelaskan makna odds ratio, untuk variabel temuan SPI sebesar 0,704 dan untuk variabel temuan atas kepatuhan sebesar 0,174. Angka-angka tersebut bermakna menjelaskan seberapa besar pengaruh variabel - variabel bebas ini terhadap variabel terikat. Pada hasil penelitian ini sebagaimana dalam tabel 4.9 maka pengaruh temuan SPI dan temuan atas pemeriksaan kepatuhan terhadap opini audit berdasarkan nilai odds ratio-nya adalah sebagai berikut:
1. Pengaruh Jumlah Temuan SPI Terhadap Opini Audit Karena data penelitian jumlah temuan SPI bernilai odds ratio sebagaimana pada tabel 4.9 yaitu sebesar 0,704, maka maknanya adalah: apabila temuan atas pemeriksaan SPI yang dilakukan oleh auditor BPK pada suatu pemerintah kabupaten/kota di Sumatera bertambah sejumlah satu kasus, maka peluang pemerintah kabupaten/kota tersebut untuk memperoleh opini WTP turun menjadi 0,704 kali, dengan asumsi jumlah temuan audit atas pemeriksaan kepatuhan terhadap peraturan perundang-undangan tetap. Ini berarti bahwa peluang suatu pemda untuk memperoleh opini WTP menjadi lebih rendah jika jumlah temuan SPI-nya bertambah dibandingkan pemda yang jumlah temuan SPI-nya tidak bertambah, atau bahkan berkurang menjadi lebih kecil, sehingga semakin besar jumlah temuan SPI maka peluang suatu pemda untuk memperoleh opini WTP semakin kecil. Dengan demikian berdasarkan hasil analisis data penelitian terhadap hipotesis satu (H1) maka diperoleh hasil empiris untuk hipotesis nol (H0) ditolak atau dengan kata lain $\mathrm{HO}$ tidak terdukung, yang berarti bahwa jumlah temuan audit SPI berpengaruh negatif terhadap opini audit. Atas hasil tersebut, maka selain terdukungnya hipotesis (H1), juga terdukungnya hasil penelitian Atmaja dan Probohudono (2015) dan setiyawati (2016). Hal ini berarti bahwa jika sistem pengendalian di suatu pemerintah daerah lemah maka akan semakin memperkecil peluang pemerintah kabupaten/kota untuk 
memperoleh opini WTP atas hasil audit atas laporan keunagannya. Masalah ini tentunya dapat menimbulkan peluang terjadi penyimpangan dan bahkan dapat terjadinya penyalahgunaan wewenang yang dapat menyebabkan pengelolaan keuangan di pemerintah daerah menjadi tidak efektif dan efisien.

2. Pengaruh Jumlah Temuan Audit Atas Kepatuhan terhadap Opini Audit Karena data penelitian jumlah temuan kepatuhan terhadap peraturan perundang- undangan bernilai odds ratio sebagaimana pada tabel

4.9 yaitu sebesar 0,174, maknanya adalah: apabila temuan atas pemeriksaan kepatuhan terhadap peraturan perundang-undangan yang dilakukan oleh auditor BPK pada suatu pemerintah kabupaten/kota di Sumatera bertambah sejumlah $1 \%$, maka peluang pemerintah kabupaten/kota tersebut untuk memperoleh opini WTP turun menjadi 0,174 kali, dengan asumsi jumlah temuan audit atas SPI tetap. Ini berarti bahwa peluang suatu pemda untuk memperoleh opini WTP menjadi jauh lebih rendah jika jumlah temuan kepatuhan terhadap peraturan perundang-undangan atas audit LKPD yang dilakukan oleh BPK bertambah, dengan kata lain semakin material jumlah temuan kepatuhan terhadap peraturan perundang-undangan maka peluang suatu pemda untuk memperoleh opini WTP semakin kecil. Dengan demikian berdasarkan hasil analisis data penelitian terhadap hipotesis dua (H2) maka telah diperoleh hasil empiris hipotesis nol (H0) ditolak atau tidak terdukung, yang berarti menerima hipotesis dua (H2), bahwa jumlah temuan audit kepatuhan terhadap peraturan perundangundangan berpengaruh negatif terhadap opini audit. Hasil ini selain terdukungnya hipotesis (H2), juga terdukungnya hasil penelitian setiyawati (2016) dan hasil penelitian Akbar dkk. (2016). Hal ini berarti bahwa jika suatu pemda kurang mematuhi norma- norma/aturan yang diatur di dalam peraturan perundangan dalam pengelolaan keuangan maka akan menciptakan temuan audit berupa indikasi kerugian, potensi kerugian, pemborosan dan berkurangnya penerimaan pemerintah, sehingga dapat terhambatnya pembangunan. Semakin material jumlah temuan atas kepatuhan ini maka akan semakin memperkecil peluang pemerintah kabupaten/kota untuk memperoleh opini WTP atas audit laporan keuangannya. Hasil audit atas SPI dan kepatuhan serta opini audit menjadi satu paket laporan hasil audit LKPD yang wajib disampaikan oleh kepala daerah kepada DPR. Hal ini merupakan wujud laporan pertanggungjawaban kepala daearahselaku agent kepada DPRD sebagai perwakilan rakyat yang merupakan principel.

Laporan pertanggungjawaban keuangan kepala daerah akan di bahas bersama seluruh anggota DPRD, yang selanjutnya dibawa kedalam sidang paripurna DPRD, untuk memutuskan menyetujui atau menolak laporan pertanggungjawaban tersebut. Jika dianggap hasil kinerja baik yang salah satu digambarkan oleh laporan hasil 
audit maka DPRD kemungkinan besar akan menerima dan mengesahkan pertanggungjawaban itu dan disetujui menjadi peraturan daerah. Dengan demikian pemerintah daerah memperoleh legitimasi rakyat melalui DPRD, dalam bentuk penerimaan dan pengesahan laporan keuangan. Dampaknya ialah semakin memperkuat posisi pemerintah, karena pemerintah dipercaya mampu mengelola keuangan daerah dengan baik. Kajian teori ini yang membuat temuan audit dan opini audit terbukti amat penting dan berarti bagi pemerintah daerah.

\section{SIMPULAN DAN SARAN}

\section{Simpulan}

Berdasarkan hasil analisis pengolahan data sampel sebanyak 146 kabupaten/kota, dari total populasi yang berjumlah 499 kabupaten/kota di Indonesia, dan pembahasan hasil statistik yang menghasilkan fakta empiris, serta kajian teori dan peraturan perundangan yang terkait, dapat ditarik beberapa kesimpulan sebagai berikut :

1. Temuan Sistem Pengendalian Internal dalam Pengelolaan keuangan negara pada Pemerintah Daerah meliputi tiga kelompok temuan, yaitu kelemahan sistem pengendalian akuntansi dan pelaporan, kelemahan sistem pelaksanaan APBD, dan kelemahan struktur pengendalian intern. Dari hasil pengujian secara empiris terhadap 146 Pemerintah kabupaten/kota di Sumatera didapatkan hasil bahwa, temuan atas sistem pengendalian intern berpengaruh negative terhadap opini audit. Hal ini berarti semakin besar jumlah temuan audit atas SPI pada pemerintah kabupaten/kota di Sumatera maka peluang suatu pemerintah kabupaten/kota itu semakin kecil untuk memperoleh opini WTP. Semakin buruk sistem pengendalian akuntansi dan pelaporan, sistem pelaksanaan APBD, dan struktur pengendalian intern yang ditandai dengan besarnya jumlah kasus temuan atas audit SPI, maka akan semakin kecil pula peluang suatu pemerintah kabupaten/kota untuk dapat memperoleh opini WTP.

2. Temuan audit atas pemeriksaan kepatuhan terhadap peraturan perundang- undangan meliputi indikasi kerugian daerah, potensi kerugian daerah, kekurangan penerimaan, pemborosan, dan ketidakefektifan. Dari hasil pengujian secara empiris terhadap 146 Pemerintah kabupaten/kota di Sumatera didapatkan hasil bahwa temuan atas pemeriksaan kepatuhan terhadap peraturan perundangundangan berpengaruh negative terhadap opini audit. Hal ini berarti semakin besar jumlah temuan audit atas pemeriksaan kepatuhan terhadap peraturan perundang-undangan pada pemerintah kabupaten/kota di Sumatera, maka peluang suatu pemerintah kabupaten/kota itu semakin kecil untuk memperoleh opini WTP. Semakin besar jumlah temuan yang terkait dengan indikasi kerugian daerah, potensi kerugian daerah, kekurangan penerimaan, pemborosan, dan ketidakefektifan maka semakin kecil peluang suatu pemerintah kabupaten/kota itu untuk memperoleh opini WTP.

\section{Saran}

Berdasarkan pada kesimpulan dan beberapa keterbatasan yang ditemukan di atas, maka untuk perhatian bagi pemerintah daerah kabupaten/kota baik 
yang telah memperoleh opini WTP, maupun yang belum berhasil memperoleh opini WTP, dan untuk penelitian selanjutnya serta untuk lembaga BPK-RI peneliti memberikan saran-saran berikut : 1. Bagi pemerintah daerah kabupaten/kota yang telah memperoleh opini WTP agar konsisten menerapkan SPI yang efektif dan meningkatkan kepatuhan terhadap peraturan perundangan, sehingga opini WTP dapat dipertahankan dan efektifitas dan efisiensi pengelolaan keuangan negara makin meningkat.

2. Bagi pemerintah daerah kabupaten/kota yang belum berhasil memperoleh opini WTP agar memperbaiki SPI dan meningkatkan kepatuhan terhadap peraturan perundangan, sehingga dapat meningkatkan peluang untuk memperoleh opini WTP, dan pengelolaan keuangan negara dapat dilaksanakan secara efektif dan efisien.

3. Bagi penelitian selanjutnya untuk waktu yang akan datang, agar penelitian yang sejenis dimungkinkan diperkaya dengan menambahkan sebaran sampel yang lebih luas lagi, dan dapat menambahkan variabel bebas dalam penelitiannya yang pada penelitian ini belum diteliti, sehingga hasil yang diperoleh diharapkan dapat lebih akurat.

4. Bagi BPK jika dimungkinkan, di masa yang akan datang dalam penyusunan standar pemeriksaan diharapkan untuk mengatur secara tegas syarat minimal dan maksimal jumlah dan nilai temuan audit baik SPI maupun kepatuhan dalam pemberian opini audit.

\section{DAFTAR PUSTAKA}

Afiah, Nunuy Nur, Peny Cahaya Azwari. 2015. The Effect Of Implementation Of Government Internal Control Sysytem (GICS) On The Quality Of Financial Report Of The Local Government And Its Impact On The Principles Of Good Governance: A Research In District, City, And Provincial Government In South Sumatera. Jurnal Elsevier, Prosedia, 811 818. Social and Behavioral sciences 2011 (2015), 2nd Global Conference On Business and Social

Science 2015, GCBSS, 17 - 18 Sept 2015, Bali, Indonesia.

Agung, Mulyo and Srihadi Winarningsih. 2016. Effect Of Auditor And Internal Control Competence Apparatus For Local Government Quality Of Financial Reporting. European Journal of Accounting, Auditing and Finance Research, Vol.4, No.7, pp.113-127, July 2016, Published by European Centre for Research Training and Development

UK (www.eajournals.org), ISSN 20546319 (Print), ISSN 20546327(online).

Asra, Abuzar, Agung Priyo Utomo, Munawar Asikin, Novi Hidayat Pusponegoro. 2017.

Analisis Multivariabel, Suatu Pengantar. Penerbit In Media, Bogor 2017. 
Ashforth, Blake E, Barrie W. Gibbs. 1990. The Double - Edge Of Organizational Legitimation. Organization Science, Vol. 1, No. 2 (1990), pp. 177-194, Published by: INFORMS, http://www.jstor.org/stable/263506 1

Akbar, Bahrullah, Moermahadi Soerja Djanegar, Achmad Djazuli, Bambang Pamungkas dan Sri Mulyani. 2016. Factors Affecting the Probability of Local Government Financial Statement to Get Unqualified Opinion. Journal The IAFOR International Conference on the Social Science Dubai 2016, Official Conference Proceedings. iafor - The International Academic Forum.www.iafor.org

Augustine, O. Enofe, Chijioke Mgbame, Lucky, G. Odeyile \& Kinglsey Kuegbe. 2013. Impact of Audit Evidence on Auditor's Report. Research Journal of Finance and Accounting. ISSN 2222- 1697 (Paper) ISSN 2222-2847 (Online). Vol.4, No.13, 2013.

Atmaja W, RM Syah Arief dan Agung Nur Probohudono. 2015. Analisis Audit BPK RI Terkait Kelemahan SPI, Temuan Ketidakpatuhan dan Kerugian Negara. Jurnal Integritas, Fakultas Ekonomi dan Bisnis Universitas Sebelas Maret, Pusat Studi Transparansi Publik dan Anti Korupsi Univesitas Sebelas Maret 2015.

Badan Pemeriksa Keuangan Republik
Indonesia. 2007. Peraturan BPK-RI No. 1 Tahun 2007 Tentang Standar Pemeriksaan Keuangan Negara.

2014. Ikhtisar Hasil Pemeriksaan Semester 1 Tahun 2014. BPK-RI 2014.

2016. Ikhtisar Hasil Pemeriksaan Semester 1 Tahun 2016. BPK-RI 2016.

COSO, Internal Control-Integrated Framework. (Committee of Sponsoring Organizations Of The Tread way Commission, 1992).

Dadang Suwanda. 2015. Factors Affecting Quality of Local Government Financial Statements to Get Unqualified Opinion (WTP) of Audit Board of the Republic of Indonesia (BPK). Research Journal of Finance and Accounting, ISSN 2222- 1697 (Paper) ISSN 22222847 (Online), Vol.6, No.4, 2015. www.iiste.org.

Ghozali, Imam. 2009. Aplikasi Analisis Multivariate dengan Program SPSS. Badan Penerbit Universitas Diponegoro, Semarang 2005.

Gregg, Bobbie McGee, Timothy F. Cercelle, 2007. How to Audit a Company's Compliance Program. Article of Management and Accounting 3(2): 52-62, 2007. http://www.hrpub.org.

Halim, Abdul dan Syukriy Abdullah. 2006. Hubungan dan Masalah Keagenan di Pemerintah Daerah : Sebuah Peluang Penelitian 
Anggaran dan Akuntansi. Jurnal Akuntansi Pemerintahan, Volume 2, Nomor 1, 2006.

Halim, Abdul dan Syukriy Abdullah. 2003. Pengaruh Dana Alokasi Umum (DAU) dan Pendapatan Asli Daerah (PAD) Terhadap Belanja Pemerintah Daerah: Studi Kasus Kabupaten/Kota di Jawa dan Bali. Jurnal Simposium Nasional Akuntansi VI, 1140-1159

Halim, Abdul. 2002. Bunga Rampai Manajemen Keuangan Daerah. Edisi Revisi.

Penerbit Yogyakarta. UPP AMP YKPN. 2007. Akuntansi Keuangan Daerah. Penerbit Salemba Empat, Jakarta 2007.

Harianto, David dan Prio Hari Adi. 2007. Hubugan Antara Dana Alokasi Umum, Belanja Modal, Pendapatan Asli Daerah dan Pendapatan per Kapita. Fakultas Ekonomi Universitas Kristen Satya Wacana Salatiga, Jurnal SNA X, di UNHAS Makasar, Juli 2007.

Heriningsih, Sucahyo. 2015. Analisis Kinerja Penyelenggara Pemerintah Daerah Dan Tingkat Korupsi, Dianalisis Dari Opini Auditor. Jurnal Akuntansi UPN "Veteran" Yogyakarta. Univesity Research Colloquium 2015, ISSN 2407- 9189.

Heriningsih, Sucahyo dan Marita. 2013. Penagruh Opini Audit Dan
Kinerja Keuangan Pemerintah.

Daerah Terhadap Tingkat Korupsi Pemerintah Daerah (Studi Empiris pada Pemerintah Kabupaten dan Kota di Pulau Jawa). Jurnal Akuntansi Universitas Pembangunan Nasioanal Veteran Yogyakarta, Buletin Ekonomi Vol. 11, No. 1, April 2013 hal 1-86.

Jensen, M. dan Meckling W. 1976. Theory of the Firm: Managerial Behavior, Agency Cost and Ownership Structure. Journal of Financial Economics, vol. 3, No. 4, pp. 305360.

Kristanto, Septian Bayu. 2009. Pengaruh ukuran pemerintahan, pendapatan asli daerah, dan belanja modal sebagai prediktor kelemahan pengendalian internal. Jurnal Akuntansi UKRIDA, vol 9, 2009 hal:1-17.

Lupia, Arthur \& Mathew Mc Cubbins. 2000. Representation or abdication? How citizens use institutions to help delegation succeed. European Journal of Political Research 37: 291- 307.

Mahmudi. 2011. Akuntansi sektor Publik. Penerbit UII Press Yogyakarta. Edisi Pertama Oktober 2011.

Messier, William, Albert Schepanski, Richard M. Tubbs, Scott D. Vandervelde. 2006. Experimental Tests of a Descriptive Theory of Combined Auditee Risk Assessment. The New England Behavioral Research Series at 
Boston College, the University of Connecticut Accounting Research Workshop, the Georgia State University Accounting Workshop, the University of Iowa Accounting Research Workshop. Electronic copy of this paper is available at: http://ssrn.com

Mustikarini, Widya Astuti dan Fitriasasi, Debby. 2012. Pengaruh Karakteristik Pemerintah Daerah dan Temuan Audit BPK Terhadap Kinerja Pemerintah Daerah Kabupaten/Kota di Indonesia Tahun Anggaran 2007. Forum: Simposium Nasional

Niktaba, Akram, Azim Aslani. 2015. The Effect Of Audit Evidence On The Auditor's Report. International Journal of Accounting Research. Publisher: ZARSMI, UAE, and Regent Business School, South Africa. Vol. 2, No. 6, 2015.

Nordiawan, Deddi, Iswahyudi Sondi Putra, Maulidah Rahmawati. 2007. Akuntansi Pemerintahan. Penerbit Salemba Empat Jakarta.

Notoatmodjo, Soekidjo. 2003. Metodologi Penelitian Kesehatan. Jakarta : Rineka Cipta

O’Donovan, Gary. 2002. Environmental disclosures in the annual report: Extending the applicability and predictive power of legitimacy theory. Accounting, Auditing \& Accountability Journal, Vol. 15 No. 3, 2002, pp. 344-371.

The current issue and full text archive of this journal is available at http://www.emeraldinsight.com

Rahayu, Dwi dan Y. Anni Aryani. 2016.

Determinasi Temuan

Pemeriksaan BPK-RI: Perspektif

Karakteristik Auditee dan

Karakteristik Auditor. Jurnal Simposium Nasional Akuntansi XIX, Lampung, 2016.

Republik Indonesi. 2003. UndangUndang Nomor 17 Tahun 2003 tentang Keuangan Negara.

2004. Undang-Undang

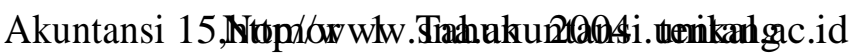
Perbendaharaan Negara.

2004. Undang-Undang Nomor 15 Tahun 2004 Tentang Pemeriksaan Pengelolaan dan Tanggung Jawab Keuangan Negara.

2014. Undang-Undang Nomor 23 Tahun 2014 tentang Pemerintah Daerah.

2005. Peraturan Pemerintah Nomor 58 Tahun 2005 tentang Pengelolaan Keuangan Daerah Daerah.

2010. Peraturan Pemerintah Nomor 71 Tahun 2010 tentang Standar Akuntansi Pemerintahan.

Santoso, Urip dan Yohanes Joni Pambelum. 2008. Pengaruh Penerapan Akuntansi Sektor Publik Terhadap Akuntabilitas Kinerja Instansi Pemerintah Dalam Mencegah Fraud. Jurnal 
Administrasi Bisnis (2008),

Vol.4, No.1: hal. 14-33, (ISSN:0216-1249), 2008 Center for Business Studies. FISIP Unpa.

Sari, Adelia Pramita, Dwi Martani dan Dyah Styaningrum. 2015. Pengaruh Temuan Audit, Tindak Lanjut Hasil Pemeriksaan dan Kualitas SDM Terhadap Opini Audit melalui Tingkat Pengungkapan Laporan Keuangan

Kementerian/Lembaga. Jurnal Akuntansi Universitas Indonesia, SNA XVIII Medan, 2015.

Sekaran, Uma. 2006. Metode Penelitian Untuk Bisnis (Terjemahan Kawan Menyon) Jakarta: Salemba Empat.

Setyaningrum, Dyah. 2012. Analisis Faktor-faktor yang Mempengaruhi Kualitas Audit BPK-RI. Jurnal SNA XV Banjarmasin, 2012.

Setiawati, Yuli. 2012. Teori Menurut Para Ahli Blog's diakses tanggal 24 Juli 2017. Setiyawati, Hari. 2016. Effect of Weaknesses of the Internal Control Systems And Non Compliance With Statutory Provisions on The Audit opinion of The Audit Board of The Republic of Indonesia. Int. Journal of Engineering Research and Application ISSN : 2248-9622, Vol. 6, Issue 9, ( Part-5) September 2016, pp.01-06 (www.ijera.com)

Simon, Yulius, Mahfud Nurnajamuddin,
Masdar Mas'ud, Muhamad Su'un. (2016). The Role Of Apparatus Competence, Internal Control System On Good Governance And The Quality Of Financial Statement Information.

Journal of Arts, Science \& Commerce. EISSN 2229- 4686, ISSN 22314172. International Refereed Research Journal www.researchersworld.com. Vol.VII, Issue - 4, Oct. 2016 [123]

Sudarsana, Hafidh Susila, Shiddiq Nur Rahardjo. 2013. Pengaruh Karakteristik Pemerintah Daerah Dan Temuan Audit BPK Terhadap Kinerja Pemerintah Daerah (Studi pada Pemerintah Kabupaten/Kota di Indonesia). Diponegoro Journal Of Accounting, Volume 2, Nomor 4, Tahun 2013, Halaman 1-13. ISSN (Online): 2337-3806.

Sugianto. 2007. Statistika untuk Penelitian. Penerbit CV Alfabeta, Bandung 2007.

Susanti, Susi dan Heru Fahlevi. 2016. Pengaruh PAD, DAU dan DBH Terhadap Belanja Modal (studi pada Kabupten dan Kota di Aceh). Jurnal Dinamika Akuntansi dan Bisnis Vol. 1, No. 1, 2016. Universitas Syiah Kuala.

Taufik, Muhammad, Darwanis, dan Muhammad Arfan. 2014. Analisi Perbedaan Kinerja Keuangan Pemerintah Daerah Periode Opini WDP dan Periode Opini WTP (Studi pada Kabupaten/kota di Provinsi Aceh Tahun 2011- 2912). 
Jurnal Akuntansi Pascasarjana Universitas Syiah Kuala. ISSN 2302-0164, Volume 3, No. 1, Februari 2014.

Tarmizi, Rosmiaty, Khairudin, dan Ayu Jayadi. 2014. Analisis Kinerja Keuangan Pemerintah Daerah Kota Bandar Lampung sebelum dan sesudah Memperoleh Opini WTP. Jurnal Akuntansi \& Keuangan, Universitas Bandar Lampung. Volume 5, Nomor 2, September 2014.
Ulum, Ihyaul M.D. 2009. Audit Sektor Publik Suatu Pengantar. Penerbit PT. Bumi Aksara, Jakarta 2009.

Usman, Husaini dan R. Purnomo Setiady Akbar. 2006. Pengantar Statistika. Jakarta, Bumi Aksara. 